\title{
Sustainable Entrepreneurship in the Light Engineering Industries: A Developing Country Perspective
}

\author{
Md. Rabiul Islam*
}

DOI: https://doi.org/10.3126/jnbs.v14i1.41472

Received on 3 June 2021

Accepted on 15 November 2021

\begin{abstract}
The study strives to generate deep insights into sustainable entrepreneurship of the Light Engineering Industries (LEIs) from a developing country perspective. This exploratory research has conducted interview schedules with a total of 450 respondents (entrepreneurs 100, workers 350) from 100 LEIs scattered in different parts of Bangladesh. The LEIs belong to the green category as indicated by the environmental regulation of Bangladesh; however, the study has found a clear lack of environmental concerns to its day-to-day practices. Deficiencies are also observed in its value chain processes. This sector is lagging to take environmental initiatives for marketing their products and creating environmental and social risk awareness among workers. In addition to these, the study has found significant deficiencies in the workers' job satisfaction, job involvement, and organizational commitment factors that are hindering organizational effectiveness. For the current entrepreneurial activities to be sustainable, this sector needs to scrutinize its product, market, value chain, industry clusters, employee motivation and environmental concerns to its day-to-day operations.
\end{abstract}

Keywords: Entrepreneurship, sustainable entrepreneurship, creating shared value, and light engineering industries

\section{INTRODUCTION}

Light Engineering Industries (LEIs) are small-sized manufacturing industries that produce machinery, equipment, tools, household appliances, electrical, electronic, and electromechanical products from metals using engineering and technological processes. This sector is now supplying spare parts, fittings for oil and gas pipelines, castings, molds, dices, and many other types of light machinery to different other industries. This sector is also providing repairing and maintenance services to other large industries such as textile, jute, cement, paper, sugar, shipping, railway, and food processing industries. The LEIs are contributing about 50 percent of spare parts to these domestic industries that were previously fully dependent on imports (BFTI, 2016). Thus, the LEIs have great potential to flourish the industrialization process of the economy. The LEIs in Bangladesh, however, are running with tremendous problems. Unavailability of skilled labor, lack of credit facilities, backdated technology, high energy-cost,

\footnotetext{
${ }^{*}$ Mr. Islam is a Professor of Management at the Department of Humanities, Rajshahi University of Engineering \& Technology (RUET), Bangladesh. E-mail: rabiul@hum.ruet.ac.bd
} 
weak institutions, lack of infrastructure, and inadequate business management and marketing strategy, etc. are inhibiting the growth of LEIs in Bangladesh (BFTI, 2016; Sharma \& Gupta, 2015; Uddin, 2010; Ahmed \&Bakht, 2010; Quadir\& Mahmud, 2009; and Rabbani, 2005). Talukdar and Jahan (2016) have added that the supporting institutions that are working for the betterment of LEIs "lack vision, resources, and understanding about the requirement of this sector" and therefore influence on the performance of the LEIs.

Despite having problems, the entrepreneurship of LEIs is contributing to the sustainable development of developing countries. Barbier (1987) viewed that "economic development of developing economies can be fostered by increasing their recognition that the overall goals of environmental conservation and economic development are not conflicting but can be mutually reinforcing". Cohen (2007) argued that "four types of market imperfections such as inefficient firms, externalities, flawed pricing mechanisms and information asymmetries at once" are degrading environment, however, the authors pointed out that these market imperfections are also "providing significant opportunities for entrepreneurs to create essential technologies and innovative business models". In this case, entrepreneurs' approach must be sustainable because "sustainable entrepreneurs create value beyond the limits of their enterprises and make positive contributions to social and ecological systems" (Belz \& Binder, 2017). Sustainable entrepreneurs also facilitate "the creation of new business opportunities innovating their ongoing activities and processes" (Urbaniec, 2018). Therefore, understanding how and to what extent sustainable entrepreneurship practices of LEIs have been creating simultaneous values to both the business and the society \& environment; evaluating the impact that sustainable entrepreneurship practices have on organizational effectiveness, and recognizing the barriers to sustainable entrepreneurship will not only help the LEIs to bring about changes in their ongoing programs but it will also promote and uphold their sustainable entrepreneurial activities in the future.

\section{LITERATURE REVIEW}

Recently, sustainable entrepreneurship has appeared as an emerging concept and received wider attention in the business and academic circles (Binder \& Belz, 2014; Camilleri, 2014). The concept 'sustainable entrepreneurship' consists of two distinct terms: entrepreneurship and sustainability. The first term 'entrepreneurship' has been viewed by Amit et al. (1993) as "a process that helps in earning profits from a novel, distinctive, and valuable combinations of resources in an uncertain environment". Eckhardt and Shane (2003) have viewed 'entrepreneurship' from an opportunity-driven standpoint. They defined "entrepreneurship as the discovery, evaluation, and exploitation of future goods and services" Eckhardt \& Shane (2003). The above definition further advanced by Stokes et al. (2010) as "a societal phenomenon or process of change consisting of three behavioral components: (i) the identification, evaluation, and exploitation of an opportunity; (ii) the management of change to facilitate the production and consumption of new goods and services; (iii) the creation of through successful exploitation of a new idea." The present study thus regarded the definition of Stokes et al. (2010) as the operational definition of entrepreneurship.

On the contrary, 'sustainability means different things to a different business, academic and environmental circles' (Atiq, 2014; Camilleri, 2014). Authors such as Camilleri (2017), Lozano (2015), Benn et al., (2014), Visser (2011), Montiel (2008), Salzmann et al. (2005), Van Marrewijk and Werre (2003), Dyllick and Hockerts (2002) have recognized that businesses have to be socially and environmentally responsible in conjunction with their financial interests. The above-mentioned authors have linked corporate sustainability construct to "a nested system" which consists of "economic, societal, and ecological process". These authors also observed that these three processes are not isolated rather inter-connected to each other for superior 
performance. Similarly, Van Marrewijk (2003) and Salzmann et al. (2005) have linked corporate sustainability imperative into value systems that could increase financial performance. Similarly, Porter and Kramer (2002) have argued that "corporate sustainability can reduce the downside operational risk when it comprises relevant performance measures that are intended to increase eco-efficiency, health and safety issues among others". Thus, "sustainable entrepreneurship is the process by which entrepreneurs consider socio-economic-environmental problems as a business opportunity to maximize value for all concerned (also in, Cohen \& Winn, 2007; Miles et al., 2009; Binder \& Belz, 2014).

The socio-economic-environmental responsibilities of corporations are in essence supported by important prior researches. For example, Pava and Krausz (1996) and Waddock and Graves (1997) viewed as 'the Virtuous Circles'; Elkington (1998) viewed as 'the Triple Bottom Line Approach'; Wheeler et al. (2003) viewed as 'The Value-Based Networks'; Wheeler et al. (2005) viewed as 'Sustainable Local Enterprise Networks'; Anderson and Markides (2007), and Landrum (2007) viewed as 'the Bottom of Pyramid Theory'; Falck and Heblich (2007) viewed as 'the Win-Win Perspective for CSR practices'; Porter \& Kramer (2011) argued as 'Creating Shared Value (CSV)'; Bhattacharya et al. (2012) viewed as 'the Stakeholder Approach to Maximizing Business and Social Value' and Husted et al. (2015) viewed as 'Value Creation through Social Strategy' among others.

It is worthwhile to note that many of the above-mentioned propositions have realized the fact that "economic progress and societal progress are mutually dependent" as is emphasized by Creating Shared Value (CSV) notion. To mean CSV Porter and Kramer (2011) "implies creating economic value through creating social value by addressing societal needs and challenges" through core products/services rather than considering social issues as a sideline business as philanthropy does. Hence, the main challenge arises concerning "how to enhance competitiveness and economic value by integrating sustainability into core business activities". In this regard, Weidinger et al. (2014) maintained that the challenge can be overcome by initiating innovations and ethics in entrepreneurial existing core business and new business solutions.

Many of the previous studies have underscored the need for the development of LEIs to attain sustainable development goals of the developing countries. Among them, Talukder and Jahan (2016) viewed that "sustained growth of the country's economy needs development of manufacturing industry supported by strong the LEIs". Haraguchi (2017) maintained that manufacturing businesses can play a significant role in the socio-economic development process of developing economies by following the path of industrialization of those countries which have already experienced a large share of manufacturing activities. Keeping rapid industrialization in mind, Hoque (2013) has attempted to explore the existing upgrading situation of LE clusters in Bangladesh. The author has used four-type of upgrading: "(a) process upgrading (b) product upgrading (c) functional upgrading (d) inter-sector upgrading". The author through case study research design has identified serious shortcomings in the existing ways of doing. Similarly, Nazish et al. (2014) in their study synthesized existing literature and explained key barriers to the growth of LEIs. To assess institutional preparedness for enhancing LEIs business performance, Talukdarand Jahan (2016) have conducted a case study research where they investigated the problems of the supporting institutions and how those problems affect the performance of the LEIs. Studies by BFTI (2016), Sharma and Gupta (2015), Uddin (2010), Ahmed and Bakht (2010), Quadir and Mahmud (2009), and Rabbani (2005) have concentrated on the characteristics, existing problems, prospects, government role, private-public collaboration, technology use, innovation progress, and policy issues related to the LEIs. This literature have also attempted to explain how the above-mentioned factors are inhibiting the growth of the LEIs in Bangladesh. However, these studies have yet to see the situation of LEIs from a sustainable entrepreneurship perspective. The present study is undertaken to fill up the research gap. 


\section{METHODOLOGY}

The study is exploratory and has used multiple case study techniques to address the research objectives. It has collected data from both primary and secondary sources. It has collected primary data from the entrepreneurs and workers of LEIs using interview schedules.

The LEIs are scattered in almost all cities and towns in Bangladesh however accurate number is not available from the Bangladesh Bureau of Statistics (BBS) because the LEIs are a composite category of the SME sector. BEIOA (2011) claims that there are almost 40,000 LE enterprises existed in Bangladesh. European Union (EU) sponsored study (2013) is supported this claim. But, the study by SEDF (sponsored by International Finance Corporation (IFC)) mentioned that there are about 7,200 LEIs in Bangladesh (in Adhikary \& McVay, 2006). Similarly, the SME Foundation of Bangladesh (2013) has claimed that there are about 6000 LEIs in the country. Because of the homogeneous characteristics, the present study has visited 100 LEIs from four different parts of Bangladesh and purposively selected 100 entrepreneurs and 350 workers for interview purposes as shown in Table 1 below:

\section{Table 1}

Participant Profile and Number

\begin{tabular}{llccc}
\hline No. & Area & No. of Firm & No. of Entrepreneur & No. of Worker \\
\hline 1. & Dhaka city & 35 & 35 & 110 \\
2. & Narayangong & 25 & 25 & 90 \\
3. & Jessore & 22 & 22 & 88 \\
4. & Bogra & 18 & 18 & 62 \\
& Total & 100 & 100 & 350
\end{tabular}

Source: Field survey (January 2020 to March 2020)

Hint: The study has not collected data from any export-oriented LEIs. All industries included are meeting local demand.

The study was facilitated with a semi-structured questionnaire before conducting in-depth interview schedules with the selected respondents to collect the primary data. Potential ethical considerations had been taken while conducting the study to reduce the harm of the participants and to reduce personal bias. It has addressed four ethical challenges: "harm to participants, lack of informed consent, invasion of privacy, and deception" identified by Bell and Bryman (2007) so that "the rights of respondents are not violated" (Miles \& Huberman, 1994). Therefore, proper arrangements were taken to inform respondents about the theme of research and its purpose, background of researcher, institutional affiliation, and time requirement for the interview. The study had also maintained ethical issues such as "avoidance or distortion of information, manipulation of data, and plagiarism" whilst using secondary sources (also in Islam, 2017; Islam et al., 2018).

\section{RESULTS AND DISCUSSION}

\subsection{Current Entrepreneurial Practices}

The LEIs are mainly serving local customers' needs. However, some of the LE items such as iron, steel, bicycle, coil and railway parts are also exported to foreign countries the major countries are: Africa, China, Australia, Japan, India, and the EU. This sector produces products and renders services according to customer demand.

One of the entrepreneurs of the LEIs opined that

"Sometimes many local customers do come to us with the order that part is not available in Bangladesh but we receive the order and produce the part customarily. Our technicians 
are capable and experienced enough to produce different kinds of spare parts. Large industries are now getting services of their machinery from the local market that's why they are saving huge amount from hiring a foreign technician."

The technician in this industry sector is mostly devoid of formal engineering education and training. They have mostly learned the techniques from doing. They worked many years as a helper of senior technicians and acquired expertise on that job. The owners of these industries have also learned this business from their predecessors. Many of them have no formal engineering education but have experience from doing it. The LEIs have a strong backward linkage. Raw materials for this sector are also found locally. In this regard, another entrepreneur of the LEIs said,

"We get raw materials from ship breaking industries situated in Chittagong. We do not have to go there for getting the supply of raw materials. We just give orders through phone calls and the suppliers send the supply at right time. Sometimes we face an acute crisis of money. They do not supply raw materials on credit. Then we have to rush for a bank loan which is not easy to get on time."

According to BEIOA, " 90 percent of raw materials for most of the items LEIs produce come from ship scrap, which comes from the domestic ship-breaking industry; the rest is sourced from Singapore, where ship scraps from all over the world come for Auction. For export quality bicycles, parts are imported from various sources like China, Turkey, and Europe".

Regarding product quality in comparison with the similar foreign product, the president of LE owners association said "foreign products are high quality but our product quality is almost similar to the foreign product. We could do it better if we had sophisticated machinery. Our machinery is mostly outdated. Even we do supply our machinery." Another entrepreneur viewed that:

The LEIs have no required technologies to meet the demand of international buyers. Most of the industries have been using traditional and outdated machines and tools. By using conventional technologies, it is not possible to meet the expectation of foreign buyers. As most of the founders of firms are illiterate, they neither have academic knowledge nor management skills. They manage the whole process using their non-academic understanding and experience.

Regarding self-employment opportunities for low-income people, many of the industry owners viewed that the LEIs have been creating self-employment opportunities for a large number of working people. Those who previously worked as labor are now opening small workshops with one or two machines in their capacity. They are not getting bank loans because they do not have any trade licenses. They are depending on micro-credit from different NGOs that charge accumulated interest rates which is much higher than that of the conventional banks. Moreover, this sector has been providing job opportunities to a large number of skilled, semi-skilled, and unskilled workers.

This sector is also providing internship/training to the students of various local Poly Technique Institutes. This process has been creating long-term social value as students are practically learning the manufacturing process.

The LEIs belong to the green category as indicated by the environmental regulation of Bangladesh (Talukdar\& Jahan, 2016) because this sector mainly produces only solid waste and re-use of scrap iron from ship-breaking industries. This sector, however, lacks environmental concerns to its day-to-day practices. There is a clear lack in its value chain process to take environmental initiatives for marketing its products and to create environmental and social risk 
awareness among workers.

Due to the nature of the operation, pollution of the working environment inside the factory is unavoidable but proper arrangements must be there to remove the wastage and effluents regularly. Environmental consciousness among industry owners, managers, and workers is a must to be sustainable but in LEIs there is a lack of environmental consciousness among them. According to a spot visit inside the factory, it is observed that workers are working where dust and fume are very much common for them. They are working without musk, finger guard, chest guard, or eye guard. Even women and child workers are working in dangerous operations. Torn and dirty clothes are common for them. Machinery and technologies they are using are also outdated which consumes extra power. No effort has been observed that can stimulate paperless works or increase the use of solar energy as an alternative source of power.

\subsection{Current Entrepreneurial Practices and Organizational Effectiveness}

This section strives to evaluate how and to what extent current performances of the LEIs are sustainable to make it effective. For this purpose, the attitude and perception of workers of the LEIs have been evaluated. The workers' attitude and perception in this regard consist of the "collection of values, beliefs, and general satisfaction on the policies and operating practices" of the LEIs (Islam, 2017). In other words, how and to what extent the day-to-day operating practices of the LEIs have been creating shared value- simultaneous business value for the entrepreneurs/owners and stakeholders of business such as workers, customers, regulators, competitors, government, and the environment. This part addresses a question like "to what extent have the LEIs have been creating shared value through fairly treating their workers?" This question was addressed through the assessment of three-kind of employee attitudes as recognized by Robbins et al. (2017-18). The attitudes include (i) employee job satisfaction, (ii) employee job involvement, and (iii) employee organizational commitment. The above-mentioned employee attitudes were again assessed based on different indicators as suggested by Robbins et al. (201718). The analysis and outcomes concerning each of the workers' attitudes are presented in the sub-sections 6.1, 6.2, and 6.3 as follows and the final remark in the sub-section 6.4.

\subsubsection{Job Satisfaction}

Workers' job satisfaction is defined by Robbins et al. (2017-18) as "a collection of positive and/or negative feelings that an individual holds toward his or her job." The study was used nine affirmative indicators to assess job satisfaction in the LEIs workers. A 5-points Likert Scale was used where weight '5' was given for strongly agree, '4' for generally agree, '3' for neither agree nor disagree, '2' for generally disagree, and '1' for strongly disagree. Hence, it is needless to say that the more of those indicators will score, the more workers' job satisfaction will be increased and the more shared value will be created. The following table summarizes the mean score regarding workers' job satisfaction indicators followed by discussion.

Regarding worker job satisfaction in the LEIs, it is apparent that majority of the workers have little or no satisfaction in their jobs. This claim is supported from Table-2 (statements JSI-1 to JSI-9) above and Appendix-A Tables 1-9 that 85.1 percent $(53.7 \%+31.4 \%)$; 91.2 percent $(60.3 \%+30.9 \%) ; 84.8$ percent $(55.1 \%+29.7 \%) ; 90.9$ percent $(60.3 \%+30.6 \%) ; 78.3$ percent $(47.7 \%+30.6 \%) ; 89.7$ percent $(58.0 \%+31.7 \%) ; 93.2$ percent $(62.6 \%+30.6 \%) ; 81.5$ percent $(50.6 \%+30.9 \%)$; and 86.8 percent $(55.4 \%+31.4 \%)$ of the respondents were strongly disagreed and disagreed combine with the positive statement whereas 14.6 percent $(14.3 \%+0.3 \%) ; 8.3$ percent $(8.3 \%+0.0 \%) ; 15.2$ percent $(14.9 \%+0.3 \%) ; 8.9$ percent; 21.7 percent $(19.1 \%+2.6 \%)$; 10.0 percent $(9.7 \%+0.3 \%) ; 6.9$ percent $(6.9 \%+0.0 \%) ; 18.3$ percent $(17.7 \%+0.6 \%)$; and 12.9 percent $(12.0 \%+0.9 \%)$ of the respondents were agreed and strongly agreed combine with the 
same statements with an average score of $1.76 ; 1.56 ; 1.75 ; 1.57 ; 1.98 ; 1.62 ; 1.51 ; 1.86 ;$ and 1.71 respectively that the grand mean of 1.70 in the scale of 5.0. These outcomes simply that in the LEIs workers' jobs are highly unsecured, absence of occupational health and safety measures, disobeying standard working time, inappropriate training, improper grievances handling, lack of information, lack of rewards and recognition for best performance (in terms of social, environmental, and financial performance), lack of encouragement regarding workers participation in the decision making process and joining workers association.

Table 2

Job Satisfaction Indicators (JSI)

\begin{tabular}{|c|c|c|c|c|c|}
\hline S.N & Indicators & Mean & Median & Mode & SD \\
\hline JSI-1 & Industry guarantee high job security & 1.76 & 1.00 & 1.00 & 1.04 \\
\hline JSI-2 & The industry ensures occupational health and safety & 1.56 & 1.00 & 1.00 & 0.86 \\
\hline JSI-3 & The industry respects standard working hours & 1.75 & 1.00 & 1.00 & 1.05 \\
\hline JSI-4 & $\begin{array}{l}\text { The industry provides appropriate training to its } \\
\text { workers }\end{array}$ & 1.57 & 1.00 & 1.00 & 0.88 \\
\hline JSI-5 & The industry addresses workers grievances properly & 1.98 & 2.00 & 1.00 & 1.21 \\
\hline JSI-6 & The industry circulate information timely & 1.62 & 1.00 & 1.00 & 0.92 \\
\hline JSI-7 & $\begin{array}{l}\text { The industry rewards and recognizes social, } \\
\text { environmental, and financial performance }\end{array}$ & 1.51 & 1.00 & 1.00 & 0.81 \\
\hline JSI-8 & $\begin{array}{l}\text { The industry encourages workers participation in } \\
\text { crucial decision making }\end{array}$ & 1.86 & 1.00 & 1.00 & 1.12 \\
\hline JSI-9 & $\begin{array}{l}\text { The industry provides for freedom of association } \\
\text { Grand Mean }\end{array}$ & $\begin{array}{c}1.71 \\
1.70\end{array}$ & 1.00 & 1.00 & 1.01 \\
\hline
\end{tabular}

Source: Field survey (January 2020 to March 2020)

\subsubsection{Job Involvement}

According to Robbins et al. $(2017,2018)$, job involvement measures the degree to which people identify psychologically with their job and consider their perceived performance level important to self-worth. Ergeneli et al. (2007) noted that employees Job Involvement is closely

\section{Table 3}

Job Involvement Indicators (JII)

\begin{tabular}{|c|c|c|c|c|c|}
\hline $\begin{array}{l}\text { Serial } \\
\text { No. }\end{array}$ & Indicators & Mean & Median & Mode & SD \\
\hline JII-1 & The job is important for career growth & 2.20 & 2.00 & 1.00 & 1.33 \\
\hline JII-2 & We feel the freedom of doing & 1.85 & 2.00 & 1.00 & 1.08 \\
\hline JII-3 & $\begin{array}{l}\text { There is a self-employment opportunity if I learn } \\
\text { this job very well }\end{array}$ & 2.18 & 2.00 & 1.00 & 1.33 \\
\hline & Grand Mean & 2.07 & & & \\
\hline
\end{tabular}

Source: Field survey (January 2020 to March 2020) 
related with psychological empowerment, which is the employees' beliefs in the degree to which they influence their work environment, their competence, the meaningfulness of their job, and their perceived autonomy. In this sub-section, three different affirmative indicators were used to measure the degree of job involvement in the LEIs workers. The following table summarizes the mean score regarding workers' job involvement indicators followed by discussion.

As for workers' job involvement in the LEIs, it is also apparent that workers have little or no job involvement (except a few) because of lack of career growth, lack of freedom of doing, and lack of self-employment opportunity as it requires capital machinery to start the business. This claim can be substantiated from Table-3 (statements JII-1 to JII-3) above and Appendix-A Tables $10-12$ that 72.9 percent $(40.6 \%+32.3 \%) ; 82.0$ percent $(49.7 \%+32.3 \%)$; and 71.7 percent $(43.4 \%$ $+28.3 \%$ ) of the respondents were strongly disagreed and disagreed combine with the positive statements whereas 27.2 percent $(20.9 \%+6.3 \%) ; 17.1$ percent $(17.1 \%+0.0 \%)$; and 28.3 percent $(23.4 \%+4.9 \%)$ of the respondents were agreed and strongly agreed with the same statements with average score of $2.20 ; 1.85$ and 2.18 respectively that the grand mean of 2.07 in the scale of 5.0 .

\subsubsection{Organizational Commitment}

Workers are treated as having organizational commitment when they "identify with a particular organization and its goals, and wishing to maintain membership in the organization" (Robbins et al., 2017-18, p.93). In this sub-section, three different affirmative indicators were used to measure the degree of organizational commitment in the LEIs workers. The following table summarizes the mean score regarding workers' organizational commitment indicators followed by discussion.

\section{Table 4}

Organizational Commitment Indicators (OCI)

\begin{tabular}{clcccc}
\hline $\begin{array}{c}\text { Serial } \\
\text { No. }\end{array}$ & \multicolumn{1}{c}{ Indicators } & Mean & Median & Mode & SD \\
\hline OCI-1 & $\begin{array}{l}\text { Possess a strong sense of "belonging" to this } \\
\text { firm }\end{array}$ & 1.76 & 1.00 & 1.00 & 1.08 \\
OCI-2 & $\begin{array}{l}\text { Often move beyond our regular duties to } \\
\text { ensure the firm's well being }\end{array}$ & 1.83 & 1.00 & 1.00 & 1.15 \\
OCI-3 & $\begin{array}{l}\text { I feel strong bondage with his firm } \\
\text { Grand Mean }\end{array}$ & $\begin{array}{c}1.66 \\
1.75\end{array}$ & 1.00 & 1.00 & 0.99 \\
\hline
\end{tabular}

Source: Field survey (January 2020 to March 2020)

Regarding workers organizational commitment, it is obvious from Table-4(statements OCI-1 to OCI-3) above and Appendix-A Tables $13-15$ that 84.9 percent $(54.9 \%+30.0 \%) ; 83.1$ percent $(53.4 \%+29.7 \%)$ and 87.1 percent $(59.1 \%+28.0 \%)$ of the respondents were strongly disagreed and disagreed combine with the positive statements while 15.1 percent $(13.7 \%+1.4 \%)$; 16.8 percent $(13.7 \%+3.1 \%)$ and $12.9(12.9 \%+0.0 \%)$ percent of the respondents were agreed and strongly agreed with the same statements with average scores of 1.76; 1.83 and 1.66 respectively that the grand mean of 1.75 in the scale of 5.0. These results expose that in the LEIs workers' sense of "belongingness" toward the industry is weak as a result of this they rarely move beyond their regular duties to ensure the industry's well-being. The outcomes also state that in the LEIs bondage between the organization and its workers is not well-built. 


\subsubsection{Ending Remark}

Table-2, Table-3, and Table-4 above have summarized mean scores concerning job satisfaction, job involvement, and organizational commitment indicators respectively in the LEIs workers. As the results show that majority of the participants were either strongly disagreed or disagreed with the affirmative statements provided from JSI-1 to JSI-9, JII-1 to JII-3, and OCI-1 to OCI-3 respectively, it can be concluded that LEIs workers have little or no job satisfaction, job involvement, and organizational commitment those are very much essential for the organizational effectiveness.

\subsection{Barriers to Sustainable Entrepreneurship}

The main barrier to sustainable entrepreneurship in the LEIs is the absence of scrutinizing value chain activities to improve productivity. The LEIs are producing spare parts and machinery for other factories using obsolete technologies and conventional machinery such as lathe, boring, milling, shaping, drilling, grinding. This sector needs computer-aided manufacturing, computeraided design, state-of-the-art heat treatment, and testing machines for the design and production of quality products.

One of the entrepreneurs said, "we cannot provide modern technologies and machinery due to the lack of money and because of the outdated machinery and technologies we cannot make efficient use of our resources (electricity, gas, manpower, raw materials, etc.)".

The LEIs have a lot of gaps in the standard practice of workers' health, safety, and working conditions. Moreover, there is inefficiency in the case of logistics and energy use. This happens mostly due to the illiteracy of the owners and workers engaged in this sector. Currently, many government and non-government organizations are working for the LEIs to provide training and other necessary support but that is inadequate compared to the need. Many of the owners of LEIs are not well educated. They have got their industry inheritably. Therefore, exploiting or even brutalizing employees is also inherited.

It is observed that a good number of LEIs are scattered all over the country. They are operating in isolation. They do not have trade licenses and that is why they do not obtain financial and counseling support from formal banking. They have to depend on micro-credit from NGOs whose interest rate is much higher than that of formal banking. Moreover, the land is essential to growing such a business. Many LEIs are situated beside the highway. If government take initiatives to establish more industrial area like BSIC and allocate among the small firms there is likely that this sector will sustain itself.

Another entrepreneur opined that,

"Bangladesh is not an industrial country. Many large industries such as jute mills, paper mills, sugar mills, cotton mills were nationalized just after the independence in 1971. But due to corruption, nepotism, bureaucratic complexity, and un-skilled management, those nationalized have been paralyzed overnight. Only private sector garment industries have been flourished because of low-cost labor. The garment sector mostly depends on imports. If government encourages those industries to purchase spare parts and machinery from the local market, then the LEIs will also flourish like the garment sector and many local and international entrepreneurs will come to invest in this sector."

There are a large number of local semi-skilled and unskilled workers available for this sector. However, skilled, educated, and experienced workers are difficult to attract and retain. The wage rate is also very cheap. It ranges from 1200 BDT to 10000 BDT per week. Many workers viewed that due to the cheap wage rate they are unable to run their family and some of them are considering working elsewhere. Regarding increasing wage rate, one of the entrepreneurs of LEI 
contend that

"We are to compete with foreign competitors and are to sell our products at a lower cost.

Moreover, we are to face stiffer local competition which ends up low-profit margin.

Therefore, we cannot increase the wage rate."

"Lack of investment in the research and development through a strong support sector appears to be one of the top constraints impeding competitiveness of the LEIs" (Talukdar \& Jahan, 2016). Around 60 percent of the costs of production of LEIs are costs of material that can be passed up by developing cost-effective materials benchmarking company activities from the developed world.

The gas and electricity crisis is also causing impediments to the LEIs. One of the entrepreneurs contend that,

"...due to the frequent changes of energy prices by the government, it is very difficult for us

to be competitive. Moreover, the electricity crisis is aggravating the problems. Being a small firm, we cannot afford self-power generating machines therefore sometimes we have to stop production, which keeps our machine and labor idle."

Finally, branding is also important for the LEIs to grow and sustain. Very few of the start-up industries in this sector have already established their brand name through high-quality product. These firms are now charging the premium price of their products and managing to spend on advertising to maintain their brand. Small LEIs, however, are far behind to establish and maintain brands because of a lack of high ambition, low-end marketing, and stiffer price competition among local firms.

\section{CONCLUSION}

The products and services of the LEIs have sufficient domestic demand from different manufacturing concerns. Due to having strong forward and backward linkage, this sector has great potential to produce import-substituting products. Moreover, it can be a source of export items because of low-cost labor. The LEIs belong to the green category as indicated by the environmental regulation of the country, however; the study has found a clear lack of environmental concerns to its day-to-day practices. Deficiencies are also observed in its value chain processes. This sector is lagging to take environmental initiatives for marketing their products and creating environmental and social risk awareness among workers. In addition to these, the study has also found significant deficiencies in the workers' job satisfaction, job involvement, and organizational commitment factors that are hindering organizational effectiveness. For the current entrepreneurship to be sustainable, this sector needs to scrutinize its value chain process to reduce energy, logistics, and resource use and to improve employee productivity. Thus, the government must come forward with adequate subsidy and organizations that are working for the betterment of LEIs must be actively and sincerely working for the marginal industries to bring a shift from informal to the formal economy.

\section{POLICY RECOMMENDATIONS}

To create upscale shared value through sustainable entrepreneurship, LEIs should:

a. Scrutinize its value chain processes to reduce energy, logistics, and resource use and to improve workers' productivity.

b. Look forward to improving the working environment. In this sector, the working environment inside the factory will inevitably be polluted due to the nature of operation but the proper arrangement must be taken to remove the wastage and effluents regularly. 
c. Workers' health and hygiene issues must be addressed properly and following the existing labor code of Bangladesh. Most of the workers are working in an unhygienic environment where dust and fume are common. The arrangement must be made to provide health-saving equipment such as masks, eye guards, gloves, chest guards, etc. during operation.

d. Child and female labor must be restricted from dangerous operations. It is common in this type of industry that most of the working people have no formal education and training. Needy children usually learn ways of production from doing as a helper therefore proper safety measures must be taken.

e. The more industrial area should be developed and allocated among the small firms that are doing business outside the BSCIC.

f. Government should provide subsidies to those LEIs that are struggling for new machinery for their plant.

g. Arrangement for a cash credit from the banking sector must be made to facilitate the LEIs to meet very short-term financial needs.

h. Bank loans and other necessary support must be provided among the female and young entrepreneurs who wish to build up a new factory. Bangladesh government has been facilitating LEIs from its different organs but the process must be speeded up and customized according to the needs of the entrepreneurs.

i. The LEIs in Bangladesh are capable of producing almost any spare part and machinery. Therefore, the government should discourage imports and encourage other industries to purchase spare parts and machinery from the local market.

j. The LEIs should take environmental initiatives for marketing their products and create environmental and social risk awareness among workers. To do so, adequate training is necessary for both the entrepreneur and worker to boost environmental consciousness.

\section{ACKNOWLEDGMENTS}

I hereby acknowledge Rajshahi University of Engineering and Technology (RUET), Bangladesh for its financial and administrative support for the conduct of the research project titled "Sustainable Entrepreneurship: Insights from Light Engineering Industries in Bangladesh". I also acknowledge that the manuscript is a part of the aforesaid research project.

\section{REFERENCES}

Adhikary, D., \& McVay, M. (2006). Market development in practice: Sector development and business services strategy. Dhaka: International Finance Corporation (IFC), the World Bank Group.

Ahmed, N., \& Bakht, Z. (2010). The light engineering industry in Bangladesh: A case study. Institute of Development Studies, 1-8.

Amit, R., Glosten, L., \& Muller, E. (1993). Challenges to theory development in entrepreneurship research. Journal of Management Studies,30 (5), 815-834.

Anderson, J., \& Markides, C. (2007). Strategic innovation at the base of the pyramid. MIT Sloan Management Review,49(1), 83-88.

Atiq, M. (2014). Sustainable corporate entrepreneurship: Insights from Pakistan (PhD diss.). 
University of Southampton. http://eprints.soton.ac.uk/365500/1.hasCoversheetVersion/Atiq, $\% 20$ Muhammad\%20fin\% 20thesis.pdf

Bangladesh SME Foundation (2013).SME clusters in Bangladesh. Dhaka: SME Foundation.

Barbier, E. (1987). The Concept of Sustainable Economic Development. Environmental Conservation, 14(2), 101-110. https://doi.org/10.1017/S0376892900011449

BEIOA (2-5 March 2011). 2nd international industrial \& engineering technology trade show \& symposium souvenir. BICC, Dhaka, Bangladesh.

Bell, E., \& Bryman, A. (March 2007). The ethics of management research: an exploratory content analysis. British Journal of Management, 18(1), 63-77. https://doi.org/10.1111/j.14678551.2006.00487.x

Belz, F.M., \& Binder, J.K. (2017). Sustainable Entrepreneurship: A Convergent Process Model. Business Strategy and the Environment, 26(1), 1-17. https://doi.org/10.1002/bse.1887

Benn, S., Dunphy, D., \& Griffiths, A. (2014). Organizational change for corporate sustainability. Routledge.

BFTI (June 2016). A study on sector-based need assessment of business promotion council- light engineering sector. Bangladesh Foreign Trade Institute (BFTI), Dhaka-1215.

Bhattacharya, C.B., Sen, S., \& Korschun, D. (2012). The stakeholder route to maximizing business and social value. Cambridge University Press.

Binder, J.K., \& Belz, F. M. (2014). Doing well by doing better: entrepreneurs and sustainability. Journal of Small Business Strategy,24(2), 1-20.

Camilleri, M.A. (2014). Advancing the sustainable tourism agenda through strategic CSR perspectives. Tourism Planning \& Development, 11(1), 42-56.

Camilleri, M.A. (2017). Corporate sustainability, social responsibility, and environmental management: an introduction to theory and practice with case studies. Springer.

Cohen, B., \& Winn, M.I. (2007). Market imperfections, opportunity, and sustainable entrepreneurship. Journal of Business Venturing, 22(1), 29-49.https://doi.org/10.1016/ j.jbusvent.2004.12.001

Dyllick T., \& Hockerts, K. (2002). Beyond the business case for corporate sustainability. Business Strategic Environment,11(2), 130-141.

Eckhardt, J., \& Shane, S.A. (2003). Opportunities and entrepreneurship. Journal of Management, 29 (3), 333-349.

Elkington, J. (1998). Partnerships from cannibals with forks: the triple bottom line of 21st century business. Environmental Quality Management, 8(1), 37-51.

Ergeneli, A., Saglam, G., \& Metin, S. (January 2007). Psychological empowerment and its relationship to trust in immediate managers. Journal of Business Research, 78, 41-49.

EU- INSPIRED (2013).Light Engineering Sector. Dhaka: EU.

Falck, O., \& Heblich, S. (2007). Corporate social responsibility: doing well by doing good. Business Horizons, 50(3), 247-254.

Haraguchi, N., Fang, C., Cheng, C., \& Smeets, E. (May 2017). The Importance of manufacturing in economic development: has this changed? World Development,93, 293-315. https://doi.org/10.1016/j.worlddev.2016.12.013

Hoque, I. (June 2013). Upgrading status of light engineering clusters in Bangladesh: an analysis. D.U. Journal of Marketing, 16(2), 1-16.

Husted, B.W., Allen, D.B. \&Kock, N. (2015). Value creation through social strategy. Business \& Society, 54(2), 147-186. 
Islam, M.R. (June 2017). Banking on shared value: A study on private commercial banks in Bangladesh (Ph.D. Diss.), Institute of Bangladesh Studies, University of Rajshahi.

Islam, M.R., Hossain, S.Z., \& Rahman, R.A. (2018). Banking on shared value: a study on IBBL in Bangladesh. Indian Journal of Science and Technology,11(8), 1-15. https://doi.org/ 10.17485/ijst/2018/v11i8/119482

Landrum, N.E. (2007). Advancing the "base of the pyramid" debate. Strategic Management Review, 1(1), 1-12.

Lozano, R. (2015). A holistic perspective on corporate sustainability drivers. Corporate Social Responsibility Environment Management, 22(1), 32-44.

Miles, M., Munilla, L. \&Darroch, J. (2009). Sustainable corporate entrepreneurship. International Entrepreneurship Management Journal, 5, 65-76.

Miles, M. B., \& Huberman, A.M. (1994).Qualitative data analysis: an expanded sourcebook. SAGE Publication.

Montiel, I. (2008). Corporate social responsibility and corporate sustainability separate pasts, common futures. Organization \&Environment,21(3), 245-269.

Nazish, A., Hussain, S.T., \& Khan,U.(2014).Barriers to the growth of small firms in Pakistan: a qualitative assessment of selected light engineering industries. The Lahore Journal of Economics, 19, 135-176.

Pava, M.L., \&Krausz, J. (1996). The association between corporate social responsibility and financial performance: the paradox of social cost. Journal of Business Ethics,15(3), 321357.

Porter, M.E., \& Kramer, M.R. (December 2002). The competitive advantage of corporate philanthropy. Harvard Business Review, 1-16. https://sharedvalue.org/sites/ default/files/resource-files/ Competitive Advant age.pdf

Porter, M.E., \& Kramer, M.R. (January-February 2011). The big idea: creating shared value; how to reinvent capitalism - and unleash a wave of innovation and growth. Harvard Business Review, 1-17. HTTPS:// businessethics.qwriting.qc.cuny.edu/files/2012/ 01/PorterKramer.pdf (accessed January 11, 2015).

Quadir, N., \& Mahamud, R. (2009). Technology, innovation, and collaboration of firms: the case of light engineering clusters in Bangladesh. Tech Monitor, 26(4), 37-41.

Rabbani, K.S. (2005). Economic policy paper on light engineering and electronics firms in Bangladesh. The DCCI-CIPE /ERRA Project, 1-73.

Robbins, S.P., Judge, T.A., \& Vohra, N. (2017, 2018). Organizational Behavior (15th ed.). Pearson Education Inc.

Salzmann, O., Ionescu-Somers, A., \& Steger, U. (2005). The business case for corporate sustainability: literature review and research options. Europena Management Review,23(1), 27-36.

Sharma, A., \& Gupta, S.K. (May-2015). Problems and prospects in the engineering industry. International Research Journal of Engineering and Technology (IRJET), 2(2), 302-404.

Stokes, D., Wilson, N., \& Mador, M. (2010). Entrepreneurship. Andover: Cengage Learning.

Talukdar, M.A., \& Jahan, S.M. (December 2016). Light engineering business ecosystem in Bangladesh: A study on institutional preparedness. IOSR Journal of Business and Management,18(12), Ver. III: 16-26.

Uddin, K.M. (2010). Bangladesh's light engineering industry, baseline, profile, performance and plans for upgrading: A study for SME Foundation. Center for Development Studies, Dhaka 7, 1-94. 
Urbaniec, M. (March 2018). Sustainable entrepreneurship: innovation-related activities in European enterprises. Polish Journal of Environmental Studies, 27(4), 1773-1779. https://doi.org/10.15244/pjoes/78155

Van Marrewijk, M. (2003). Concepts and definitions of CSR and corporate sustainability: Between agency and communion. Journal of Business Ethics, 44(2), 95-105.

Van Marrewijk, M., \& Werre, M. (2003). Multiple levels of corporate sustainability. Journal of Business Ethics, 44(2), 107-119.

Visser, W. (2011).The age of responsibility: CSR 2.0 and the new DNA of business. Chichester, West Sussex, U.K.: John Wiley \& Sons.

Waddock, S. (2008). Building a new institutional infrastructure for corporate responsibility. AcadManagPerspect, 22(3), 87-108. https://doi.org/10.5465/amp.2008.34587997

Weidinger, C., Fischler, F., \& Schmidpeter, R. (Eds.) (2014). Sustainable Entrepreneurship: Business Success through Sustainability. Springer-Verlag.

Wheeler, D., Colbert, B. \& Freeman, R.E. (2003). Focusing on value: Reconciling corporate social responsibility, sustainability and a stakeholder approach in a networked world. Journal of General Management,28(3), 1-28.

Wheeler, D., McKague, K., Thomson, J., Davies, R., Medalye, J., \& Prada, M. (2005). Creating sustainable local enterprise networks. MIT Sloan Management Review,47(1), 33-40.

\section{Appendix A}

\section{Detail Survey Results of Stakeholders Perception}

Table A.1

Job Security

\begin{tabular}{lrrr}
\hline \multicolumn{1}{c}{ Level of Agreement } & Frequency & Percent & Cumulative Percent \\
\hline Strongly disagree & 188 & 53.7 & 53.7 \\
Disagree & 110 & 31.4 & 85.1 \\
Neutral & 1 & .3 & 85.4 \\
Agree & 50 & 14.3 & 99.7 \\
Strongly agree & 1 & .3 & 100.0 \\
\hline Total & 350 & 100.0 & \\
\hline
\end{tabular}

Source: Field survey (January 2020 to March 2020)

Table A.2

Occupational Health and Safety

\begin{tabular}{lrrr}
\hline \multicolumn{1}{c}{ Level of Agreement } & Frequency & Percent & Cumulative Percent \\
\cline { 1 - 2 } \cline { 3 - 4 } Strongly Disagree & 211 & 60.3 & 60.3 \\
Disagree & 108 & 30.9 & 91.1 \\
Neutral & 2 & .6 & 91.7 \\
Agree & 29 & 8.3 & 100.0 \\
\hline Total & 350 & 100.0 & \\
\hline
\end{tabular}

Source: Field survey (January 2020 to March 2020) 
Table A.3

Standard Working Hours

\begin{tabular}{lrrr}
\hline \multicolumn{1}{c}{ Level of Agreement } & Frequency & Percent & Cumulative Percent \\
\hline Strongly Disagree & 193 & 55.1 & 55.1 \\
Disagree & 104 & 29.7 & 84.9 \\
Agree & 52 & 14.9 & 99.7 \\
Strongly agree & 1 & .3 & 100.0 \\
Total & 350 & 100.0 & \\
\hline
\end{tabular}

Source: Field survey (January 2020 to March 2020)

Table A.4

Appropriateness of Training

\begin{tabular}{lrrr}
\hline \multicolumn{1}{c}{ Level of Agreement } & Frequency & Percent & Cumulative Percent \\
\hline Strongly Disagree & 211 & 60.3 & 60.3 \\
Disagree & 107 & 30.6 & 90.9 \\
Neutral & 1 & .3 & 91.1 \\
Agree & 31 & 8.9 & 100.0 \\
\hline Total & 350 & 100.0 & \\
\hline
\end{tabular}

Source: Field survey (January 2020 to March 2020)

Table A.5

Handling Workers Grievances

\begin{tabular}{lrrr}
\hline \multicolumn{1}{c}{ Level of Agreement } & Frequency & Percent & Cumulative Percent \\
\hline Strongly Disagree & 167 & 47.7 & 47.7 \\
Disagree & 107 & 30.6 & 78.3 \\
Agree & 67 & 19.1 & 97.4 \\
Strongly agree & 9 & 2.6 & 100.0 \\
\hline Total & 350 & 100.0 & \\
\hline
\end{tabular}

Source: Field survey (January 2020 to March 2020)

Table A.6

Dissemination of Timely Information

\begin{tabular}{lrrr}
\hline \multicolumn{1}{c}{ Level of Agreement } & Frequency & Percent & Cumulative Percent \\
\hline Strongly Disagree & 203 & 58.0 & 58.0 \\
Disagree & 111 & 31.7 & 89.7 \\
Neutral & 1 & .3 & 90.0 \\
Agree & 34 & 9.7 & 99.7 \\
Strongly agree & 1 & .3 & 100.0 \\
\hline Total & 350 & 100.0 &
\end{tabular}

Source: Field survey (January 2020 to March 2020)

Table A.7

Rewards and Recognition of Best Performance

\begin{tabular}{lrrr}
\hline \multicolumn{1}{c}{ Level of Agreement } & Frequency & Percent & Cumulative Percent \\
\hline Strongly disagree & 219 & 62.6 & 62.6 \\
Disagree & 107 & 30.6 & 93.1 \\
Agree & 24 & 6.9 & 100.0 \\
\hline Total & 350 & 100.0 & \\
\hline
\end{tabular}

Source: Field survey (January 2020 to March 2020) 
Table A.8

Workers Participation in Crucial Decision Making

\begin{tabular}{lrrr}
\hline \multicolumn{1}{c}{ Level of Agreement } & Frequency & Percent & Cumulative Percent \\
\hline Strongly disagree & 177 & 50.6 & 50.6 \\
Disagree & 108 & 30.9 & 81.4 \\
Neutral & 1 & .3 & 81.7 \\
Agree & 62 & 17.7 & 99.4 \\
Strongly agree & 2 & .6 & 100.0 \\
\hline Total & 350 & 100.0 & \\
\hline
\end{tabular}

Source: Field survey (January 2020 to March 2020)

Table A.9

Freedom of Association

\begin{tabular}{lrrr}
\hline \multicolumn{1}{c}{ Level of Agreement } & Frequency & Percent & Cumulative Percent \\
\hline Strongly disagree & 194 & 55.4 & 55.4 \\
Disagree & 110 & 31.4 & 86.9 \\
Neutral & 1 & .3 & 87.1 \\
Agree & 42 & 12.0 & 99.1 \\
Strongly agree & 3 & .9 & 100.0 \\
\hline Total & 350 & 100.0 & \\
\hline
\end{tabular}

Source: Field survey (January 2020 to March 2020)

Table A.10

Career Growth

\begin{tabular}{lrrr}
\hline \multicolumn{1}{c}{ Level of Agreement } & Frequency & Percent & Cumulative Percent \\
\hline Strongly disagree & 142 & 40.6 & 40.6 \\
Disagree & 113 & 32.3 & 72.9 \\
Agree & 73 & 20.9 & 93.7 \\
Strongly agree & 22 & 6.3 & 100.0 \\
\hline Total & 350 & 100.0 & \\
\hline
\end{tabular}

Source: Field survey (January 2020 to March 2020)

Table A.11

Freedom of Doing Level of Agreement Frequency Percent Cumulative Percent

\begin{tabular}{lrrr}
\hline Strongly disagree & 174 & 49.7 & 49.7 \\
Disagree & 113 & 32.3 & 82.0 \\
Neutral & 3 & .9 & 82.9 \\
Agree & 60 & 17.1 & 100.0 \\
\hline Total & 350 & 100.0 & \\
\hline
\end{tabular}

Source: Field survey (January 2020 to March 2020) 
Table A.12

Self-employment Opportunity

\begin{tabular}{lrrr}
\hline \multicolumn{1}{c}{ Level of Agreement } & Frequency & Percent & Cumulative Percent \\
\hline Strongly disagree & 152 & 43.4 & 43.4 \\
Disagree & 99 & 28.3 & 71.7 \\
Agree & 82 & 23.4 & 95.1 \\
Strongly agree & 17 & 4.9 & 100.0 \\
\hline Total & 350 & 100.0 & \\
\hline
\end{tabular}

Source: Field survey (January 2020 to March 2020)

\section{Table A.13}

Sense of Belongingness

\begin{tabular}{lrrr}
\hline \multicolumn{1}{c}{ Level of Agreement } & Frequency & Percent & Cumulative Percent \\
\hline Strongly disagree & 192 & 54.9 & 54.9 \\
Disagree & 105 & 30.0 & 84.9 \\
Agree & 48 & 13.7 & 98.6 \\
Strongly agree & 5 & 1.4 & 100.0 \\
\hline Total & 350 & 100.0 & \\
\hline
\end{tabular}

Source: Field survey (January 2020 to March 2020)

Table A.14

Extra Duties for Industry's Well Being

\begin{tabular}{lrrr}
\hline \multicolumn{1}{c}{ Level of Agreement } & Frequency & Percent & Cumulative Percent \\
\hline Strongly disagree & 187 & 53.4 & 53.4 \\
Disagree & 104 & 29.7 & 83.1 \\
Agree & 48 & 13.7 & 96.9 \\
Strongly agree & 11 & 3.1 & 100.0 \\
\hline Total & 350 & 100.0 & \\
\hline
\end{tabular}

Source: Field survey (January 2020 to March 2020)

Table A.15

Bondage between Organization and Its Workers

\begin{tabular}{lrrr}
\hline \multicolumn{1}{c}{ Level of Agreement } & Frequency & Percent & Cumulative Percent \\
\hline Strongly disagree & 207 & 59.1 & 59.1 \\
Disagree & 98 & 28.0 & 87.1 \\
Agree & 45 & 12.9 & 100.0 \\
\hline Total & 350 & 100.0 & \\
\hline
\end{tabular}

Source: Field survey (January 2020 to March 2020) 